\title{
Infertility Caused by Jinn
}

\author{
Mira Bajirova* \\ Department of Obstetrics and Gynecology, Healthcare Medical Center, Dubai, UAE
}

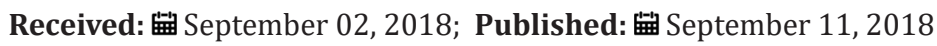

*Corresponding author: Mira Bajirova, Department of Obstetrics and Gynecology, Healthcare Medical Center, Dubai, UAE

\begin{abstract}
The World of Jinn is both sinister and intriguing. Their supernatural power (invisible in their natural state, shape-shifter, flying around the World in a second, illusion creation, possibility to possess the humans and create all kind of problems and even kill) can explain the mysteries, the diseases with unknown causes, unexplained Infertility. Knowing the traps of Shaytan (Satan or Devil or Evil Jinn) will help to diagnose properly and to remove the Evil of Shaytan. The Treatment of the Infertility (and of the diseases) caused by Black Magic or Jinn Possession or Evil Eye is only Ruqya, the specific verses of the Noble Quran, combined with the Negative Ions treatment for the quicker and better results.
\end{abstract}

Keywords: Jinn; The Supernatural Power; Infertility; Ruqya; Quran; Negative Ions

\section{Introduction}

In the modern society the Jinn is categorized as paranormal or parapsychological or most of the people is not aware or do not believe or ignore. But the lack of the knowledge or ignorance is dangerous as the Evil Jinn is our real enemy and not only badly interfering in all aspect of our life, creating many problems including the health issues but the main purpose of the Satan is to bring maximum people to the eternal life in the Hellfire. This life is short, temporary and only test. The eternal life is after the death and there are only two final destinations: Paradise or Hellfire. For the people who will enter Hellfire, this life would appear like one day. To enter to the Paradise, we should follow strictly the Allah's commands and Sunnah. Unfortunately, people think that it is only for Muslims. The Guidance (Quran and Sunnah) is for all Mankind and Jinn who wants Eternal Life in the Paradise.

“Those who deny the Jinn's existence do not have evidence to support their denial. They merely have a lack of knowledge because the beliefs and experimental knowledge of their profession contain nothing which confirms the Jinn's existence. Such a case of medical doctor who looks after the health of the body by treating the physical symptoms of its sicknesses from the point of view of changes of its physical make up without considering what may can happen to the body from the spiritual point of view or what may happen to the body because of the effect of the Jinn on it. This is often the case even so though he may have learned through means other than his medicine that the soul has greater effect on the body then his medicinal remedies" [1]. The Jinn are an established World, unseen World, living beside the humans. The word Jinn itself comes from the Arabic root meaning "something hidden which cannot be seen" [1,2].

"The Shaytan is present with any one of you in all his affairs." (Muslim, 2033). As the Evil Jinn is involved in all aspects of our life, they create all problems including the infertility. Knowing the real enemy of humans is important to protect our families and to follow the straight path of Allah. Their purpose in life is the same as ours, as Allah (Subhanahu wa ta'ala in Arabic for "May He be glorified and exalted") says: "I did not create the Jinn and mankind except to worship Me" (Quran, Adh-Dhariyat 51:56). The existence of the Jinn is firmly corroborated by the Quran and Sunnah, and thus one who denies their existence is outside of Islam, it means, outside of the Paradise. Suffice it to say that the word Jinn occurs more than 29 times in the Qur'an, and the word Shaytan and its plural Shayaateen together occur more than 80 times. There is an entire surah called Surah al-Jinn (Quran, Al Jinn 72) which speaks in clear, explicit terms about the Jinn. "And thus, we have made for every prophet an enemy - devils from mankind and jinn, inspiring to one another decorative speech in delusion. But if your Lord had willed, they would not have done it, so leave them and that which they invent." (Quran Al An'am 6:112).

It was narrated that 'Abd-Allaah ibn Mas'ood said: The Messenger of Allah (salla Allahu alayhi wa sallam or piece and .... ) 
said: "There is no one among you but a companion from among the Jinn has been assigned to him." Constant Jinn companion, Qareen, is attached to every human since the birth. The Prophet Muhammad (salla Allahu alayhi wa sallam) said why the child cries at birth: "When any human being is born, Satan pinches the body with his two fingers, except 'Isa, the son of Maryam, whom Satan tried to pinch but failed, for he touched the placenta instead" (Bukhari 4:506). The Azhan (call for the prayer) should be recited into the baby's right ear so that the first thing he hears in this world will be the words of Tawheed, which will have a great and blessed effect on the child. We are tested to see which the true servants of Allah are and which only follow their desires. If we do not follow the Allah's commands and prohibitions, we follow the footsteps of Shaytan. It was narrated that Jaabir (may Allah be pleased with him) said: I heard the Prophet (salla Allahu alayhi wa sallam) said: "Indeed, Allah knows the unseen (aspects) of the heavens and the earth. And Allah is Seeing of what you do." (Quran, Al Hujurat 49:18)

\section{Shaytan is the Source of all Evil}

The Disbelieving Jinn (Shaytan, Satan, devil) is our real enemy. Knowing Shaytan we start to understand the mysteries, the corruption, the war, robbery, suicide, murder, corruption, immorality, enmity, hatred, the relationship and marriage breaking, fornication, prostitution, homosexuality, health issues, alcohol and narcotics addiction, psychiatric diseases, arrogance, pride, selfsufficiency, worshiping the idols or Shaytan; all the work of Shaytan to corrupt the mankind and to drive people away from Allah, to the Hellfire with him. There are many diseases caused by Evil Jinn (Black Magic, Jinn Possession and Evil Eye) and the cure is only with Ruqya, the specific verses of Quran [3,4]. Instead of Ruqya most of doctors have no idea about Quran and those having knowledge do not implement Ruqya in their practice and instead they use expensive and in the most cases inefficient modern medicine. Demonic possession is Pre-Islamic, it is only in Quran Allah (Subhanahu wa ta'ala) reveals in more details the Unseen World and especially the different ways of the protection from the Qareen (Jinn attached to every person), Human Evil and the Evil Jinn.

Sheikh Ibn Taymiyyah (may Allah be pleased with him) at the beginning of the 13th century told that if we would have removed the veil we would have seen $50 \%$ of the population affected by Jinn. What to tell nowadays in our unstable World with the war, insecurity, terrorism, crime, robbery, corruption, immorality, hatred, jealousy, fornication, prostitution, homosexuality, narcotics and alcohol addiction, dispute, discrimination, maybe $90 \%$ of the population is affected by Jinn? In a World where human weakness from temptations and weakness of faith abound, Shaytan influences man into ignoring the words of our Creator, Allah (Subhanahu wa ta'ala), Quran. He thus overly engages man into running after the worldly goals at the expense of violating Divine commandments. Another common way for the Satan is to make us compare our situations with those around us and arousing feelings of envy and jealousy. Shaytan induces the laziness and procrastination to keep one away from doing the good deeds and to be on time for the job and even for the prayer. Iblees- the Shaytan (devil), wicked Jinn, trying to scare, confuse, trouble, pushing us away from the good, tempt us to do the evil, corrupt us, and will be with us until our last breath, trying many tricky ways to bring us to the Hellfire. Satan makes one quickly assume something negative about the other, infuses the suspicion and doubt in the hearts and provoking people against one another.

The Prophet (salla Allahu alayhi wa sallam) said: "Iblees places his throne upon water; he then sends detachments (for creating dissension between people); the nearer to him in rank are those who are most notorious in creating dissension. One of them comes and says: "I did so and so." And he says: "You have done nothing." Then one amongst them comes and says: "I did not spare so and so until I sowed the seed of discord between a husband and a wife." Shaytan goes near him and says: "You have done well." He then embraces him" (Sahih Muslim and narrated by Jabir Ibn 'Abdullah). "And Shaytan will say when the matter has been decided: 'Verily, Allah promised you a promise of truth. And I too promised you, but I betrayed you. I had no authority over you except that I called you, and you responded to me. So, blame me not, but blame yourselves. I cannot help you, nor can you help me. I deny your former act in associating me (Satan) as a partner with Allah (by obeying me in the life of the World). Verily, there is a painful torment for the Zaalimoon (polytheists and wrongdoers)'” (Quran, Ibrahim: 22).

Allah Almighty (Subhanahu wa ta'ala) says: "His Companion will say: "Our Lord! I did not make him transgress, but he was (himself) far astray." (Quran, Qaf 50: 27) i.e. the Shaytan assigned to seduce him will say: "My Lord! It was not me who seduced him at the beginning, but it was he himself who preferred blindness to guidance. So, I helped him achieve his goal through seduction." "Satan promises them and arouses desire in them. But Satan does not promise them except delusion. (Quran, A Nisa 4:120) The Messenger of Allah (sallallahu alaihi wasallam) said: 'The Jinn are of three types: a type that has wings, and they fly through the air; a type that looks like snakes and dogs; and a type that stops for a rest then resumes its journey." (Reported by al-Tahhaawi in Mushkil al-Athaar, 4/95, and by al-Tabaraani in al-Kabeer, 22/214. Shaykh al-Albaani said in al-Mishkaat (2/1206, no. 4148). As a whole the Jinn are rather mischievous to downright untrustworthy (they are deceptive liars), although some Jinn amended ways and converted to Islam (Quran, Al Jinn 72) It is a great blessing that Allah (Subhanahu wa ta'ala) sent down to the all mankind (not only for Muslims) and Jinn the Quran: "This is the Book about which there is no doubt, Guidance for those conscious of Allah. Who believe in the unseen, establish prayer, and spend out of what We have provided for them" (Quran, Al Baqarah 2:2,3). "The believers are only those who, when Allah is mentioned, their hearts become fearful, and when His verses are recited to them, it increases them in faith; and upon their Lord they rely" (Quran, Al-Anfal 8:2). The characteristics of Jinn compared to Humans are illustrated in the Tables 1-10. 
Table 1:

\begin{tabular}{|c|c|c|}
\hline \multicolumn{3}{|c|}{ JINN are like HUMANS } \\
\hline & JINN & MANKIND \\
\hline FEMALE and MALE & Female and Male & Female and Male \\
\hline REPRODUCTION & children & children \\
\hline SEXUALITY & $\begin{array}{l}\text { JNN-JNN, JNN-HUMAN } \\
\text { HOMOSEXUALITY }\end{array}$ & \\
\hline $\begin{array}{l}\text { EAT and DRINK } \\
\text { RELIGION }\end{array}$ & $\begin{array}{l}\text { Eat and drink } \\
\text { BELEVERS and DISBELIEVERS }\end{array}$ & $\begin{array}{l}\text { Eat and drink } \\
\text { same }\end{array}$ \\
\hline FREE WILL & $\begin{array}{l}\text { GOOD and BAD, } \\
\text { RIGHT and WRONG }\end{array}$ & same \\
\hline \multicolumn{3}{|l|}{ DEATH (except Iblees) } \\
\hline $\begin{array}{l}\text { ACCOUNTABLE } \\
\text { JUDGMENT DAY }\end{array}$ & $\begin{array}{l}\text { SUBJECT to } \\
\text { ALLAH'S CONMANDS and PROHIBITONS }\end{array}$ & same \\
\hline
\end{tabular}

Table 2:

\begin{tabular}{|c|c|c|}
\hline & JINN & MANKIND \\
\hline EAT and DRINK & $\begin{array}{c}\text { LEFT HAND } \\
\text { BONES and DUNG }\end{array}$ & $\begin{array}{l}\text { RIGHT HAND } \\
\text { "When one of you eats, let him eat } \\
\text { with his right hand, and when he } \\
\text { drinks, let him drink with his right } \\
\text { hand. Verily, the deril eats and } \\
\text { drinks with his left hand." } \\
\text { (Sahih Muslim 2020) }\end{array}$ \\
\hline REPRODUCTION & Shaytan by laying the EGGS & \\
\hline SEXUALTY & HOMOSEXUALTY is HIGHER & \\
\hline NUMBER & MUCH MORE & \\
\hline DEATH & $\begin{array}{l}\text { LVE LONGER } \\
\text { IBLEES until the JUDGMENT DAY }\end{array}$ & \\
\hline
\end{tabular}

Table 3:

\begin{tabular}{|c|c|c|}
\hline \multicolumn{3}{|c|}{ JINN and MANKIND DIFFERENCIES } \\
\hline & JINN & MANKIND \\
\hline CREATION & $\begin{array}{c}\text { BEFORE MANKIND } \\
\text { SMOKELESS FIRE } \\
\text { “And the jinn We created before from } \\
\text { scorching fire." } \\
\text { (Surah Hijr 15: 26-27) }\end{array}$ & $\begin{array}{l}\text { CLAY } \\
\text { “And We did certainly } \\
\text { create man out of clay from } \\
\text { an altered black mud." }\end{array}$ \\
\hline UNSEEN APPEARANCE & $\begin{array}{l}\text {-NVISIBLE in their NATURAL State } \\
\text { "Indeed, he sees you, he and his tribe, from } \\
\text { where you do not see them. " } \\
\text { (Quran, Al Araf 7:27 }\end{array}$ & \\
\hline PHYSICAL APPEARANCE & $\begin{array}{c}\text { ANY PHYSICALFORMS } \\
\text { SHAPE-SHIFTER } \\
\text { Human, Human-Animal, Black Dog, Black Cat, } \\
\text { Snake, Scorpion, Camel,Donkey, Tree, Plaint.. }\end{array}$ & \\
\hline
\end{tabular}

Table 4:

\section{JINN and MANKIND DIFFERENCIES}

\begin{tabular}{|l|l|l|}
\hline PHYSICAL LOOKING & \multicolumn{1}{|c|}{ IINN } & MANKIN Unpleasant, Repulsive-looking, \\
& $\begin{array}{l}\text { The branches of Zaggoom (a tree in Hell) is } \\
\text { compared in the Quran to the heads of devils: } \\
\text { "Verily, it is a tree that springs out of the bottom of } \\
\text { Hell-Fire. The shoots of its fruit-stalks are like the } \\
\text { heads of devils"(Quran 37:64-65). }\end{array}$ \\
\hline DISBELIENING JNN & $\begin{array}{l}\text { Arrogance, rebellious, pride, harsh, malevolent, } \\
\text { CHARACTERISTICS } \\
\text { disobedient, malicious, stubborn, liar, pledger, } \\
\text { jealous, hypocrite, deceiving, mischief-maker, } \\
\text { vengeful, harmful, disturbing, aggressive, } \\
\text { spoiling our thoughts and hearts with the evil } \\
\text { inclinations }\end{array}$ \\
\hline
\end{tabular}

Table 5:

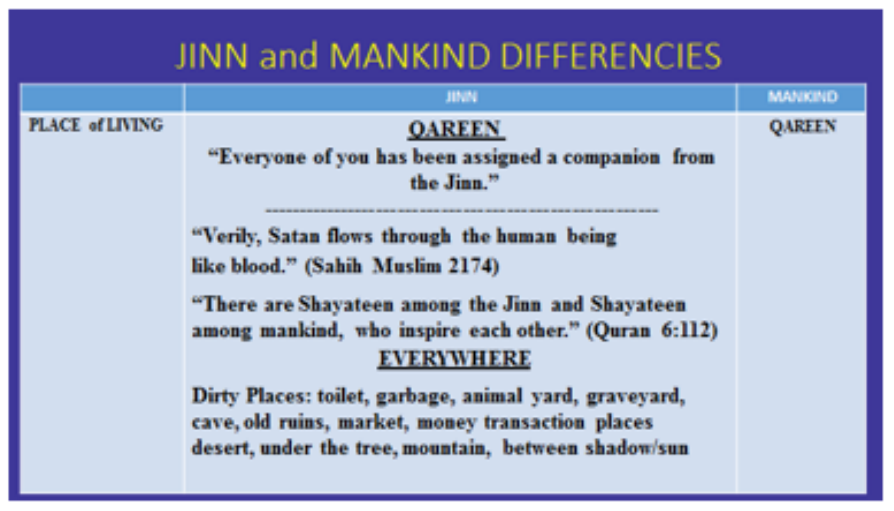

Table 6:

\begin{tabular}{|l|l|l|}
\hline \multicolumn{2}{|l}{ JINN and MANKIND DIFFERENCIES } \\
\hline SUPERNATURAL & $\begin{array}{l}\text {-Fly with Light speed } \\
\text { POWER } \\
\text { (travel around the World in a blink of eye) } \\
\text {-"Shape-shift" (invisible-visible) } \\
\text {-Illusion Creation (halal-haram, right-wrong, trust-mistrust, } \\
\text { certainty-suspicion, sureness-doubt, small-big, beautiful-ugly, } \\
\text { appear-disappear, fixed-movable, one thing is replaced by } \\
\text { another etc) } \\
\text {-Stronger (can move heavy things in a second) } \\
\text {-Possess and trouble humans with no or weak faith: } \\
\text { Jinn possession, Black Magic, Evil Eye }\end{array}$ \\
\hline
\end{tabular}

Table 7:

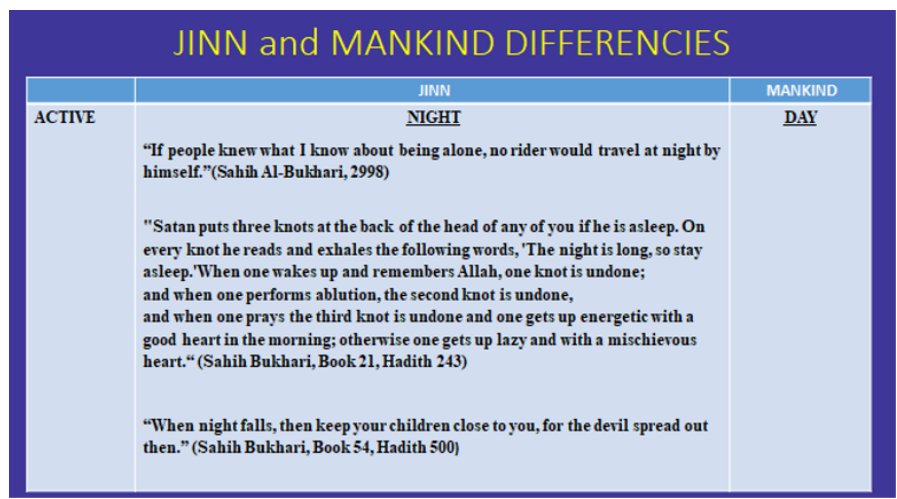

Table 8:

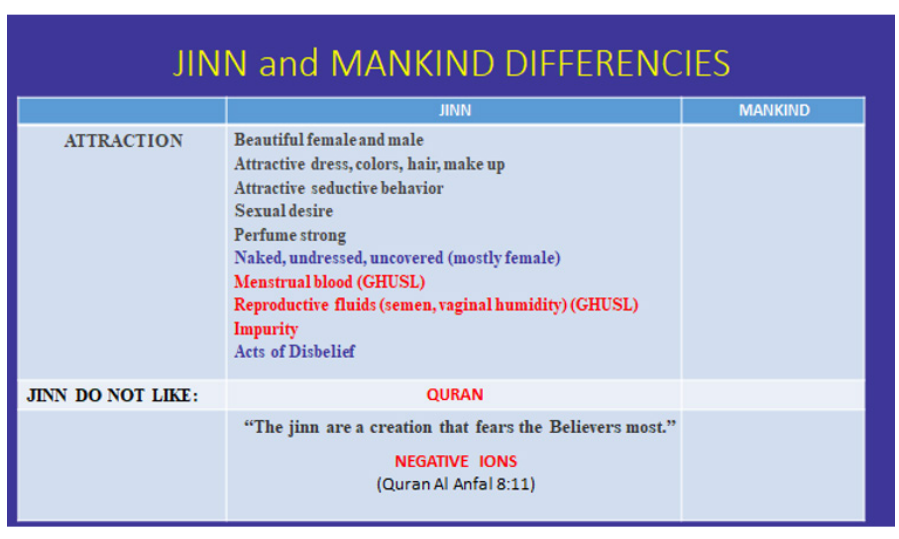


Table 9:

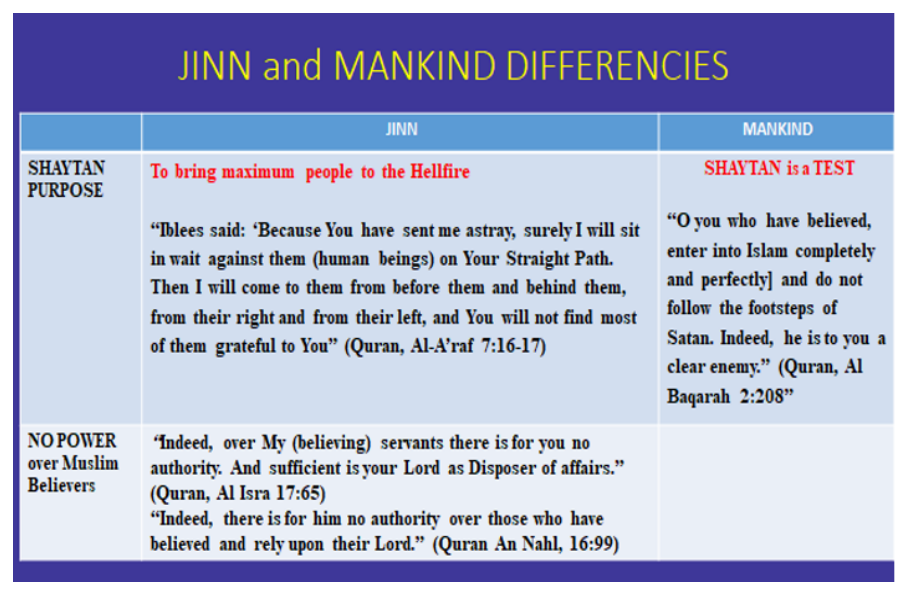

Life is a Test. We are tested by Qareen, the Jinn attached to everyone since the birth, by Evil of Humans and by Evil Jinn (parallel Unseen World). "And of the people is he who disputes about Allah without knowledge and follows every rebellious devil." (Quran Al Hajj 22:3) "Will you then take (Iblees) and his offspring as protectors in preference to Me, although they are an enemy to you?" (Quran, Al Kahf 18:50) "Did I not enjoin upon you, O children of Adam, that you not worship Satan - (for) indeed, he is to you a clear enemy. And that you worship (only) Me? This is a straight path. And he had already led astray from among you much of creation, so did you not use reason? This is the Hellfire which you were promised." (Quran, Yasin 36:60-64) "Verily! The worst of moving living creatures in the Sight of Allah are the deaf and the dumb, those who understand not - the disbelievers."(Quran, Al Anfal 8:22) "They are only like cattle - nay, they are even further astray from the Path - even worse than cattle."(Quran Al Furqan 25:44)

The Jinn plague the houses, cause the disturbances by throwing small household items, moving the different objects, the furniture; stones may be thrown at or in houses, appearing to come from nowhere; they switch off the light; fires may be set inexplicably. All of that happens by the will and decree of Allah (Subhanahu wa ta'ala). "Indeed, all things We created with predestination" (Quran, $\mathrm{Al}$ Qamar 54:49) "It is Allah who has created seven heavens and of the earth, the like of them. [His] command descends among them, so you may know that Allah is over all things competent and that Allah has encompassed all things in knowledge." (Quran, Al-Talaq 65:12) "Say: "None in the heavens and the earth knows the Ghaib (Unseen) except Allah" (Quran, Al-Naml 27:65) Correspondences between Jinn and Humans interfere in our lives in a subtle and hidden manner. "The shaytan flows through the sons of Adam like blood." (Sahih Muslim 2174) The Evil Jinn affect the humans via Black Magic, Jinn Possession and Evil Eye.

\section{BLACK MAGIC- WITCHCRAFT-SIHR}

According Imam Abdul-Aziz Ibn Baz: Sihr or Sorcery as defined by Islamic law consists of charms or incantations that are composed to cause illness, loss of mental stability, death, to separate spouses from each other, or to prevent a man from acts of intimacy with his wife [5]. The Jinn's supernatural powers: flying with light speed, ability to "shape-shift" (passing from invisible to physical forms), moving heavy things in a second, creating the illusions, and possessing the mind and body of other creatures; have been used by Fortune-tellers even before Islam. Voodoo, Tarot, Poltergeists, Witchcraft, Astrology, Horoscope, Palm, Coffee, Tea Leaves reading, Clairvoyant, Spaewife, Soothsayer, Medium, Zar Zar dance: all these involve the Jinn. The effects of the Jinn are not just limited to Fortune-tellers. The activities such as oujia boards and seances, used to contact the dead, are manipulated by the Jinn. Other biggest manipulations of the Jinn are through visions and voices. Only by having knowledge of the World of the Jinn and faith in Allah, we can fight such a trial by the will of Allah. The countless numbers of visions of Jesus Christ and the Virgin Mary over the centuries have been a popular choice for the devils.

Before the arrival of Prophet Muhammad (sallallahu Alaihi wa sallam) the devils had taken sitting stations for themselves in the heaven and they would listen to the matters that occurred in the heaven, stealing the information about the future. That time the Fortune Tellers were more accurate about future prediction. But when Allah (Subhanahu wa ta'ala) sent Muhammad as a Messenger, they were suddenly pelted one night (with the flaming, shooting stars). "Indeed, we have adorned the nearest heaven with an adornment of stars. And as protection against every rebellious devil. And We have protected it from every devil expelled (from the mercy of Allah). Except one who steals a hearing and is pursued by a clear burning flame" (Quran, Al Hijr 15:16-18)

"Indeed, we have adorned the nearest heaven with an adornment of stars. And as protection against every rebellious devil. (So) they may not listen to the exalted assembly (of angels) and are pelted from every side, repelled; and for them is a constant punishment. Except one who snatches [some words] by theft, but they are pursued by a burning flame, piercing (in brightness)." (Quran As-Saffat 37: [6-10]) "And we have sought (to reach) the heaven but found it filled with powerful guards and burning flames. And we used to sit therein in positions for hearing, but whoever listens now will find a burning flame lying in wait for him." (Quran, Al Jinn 72:8-9)

The Hadith describes how the Jinn climb one on top of the other to the heavens, where Allah (Subhanahu wa ta'ala) decrees a matter in the presence of Angels. Jinn will hear some information in stealth, and if not burned by a flame, passes it down below, one after another until it reaches earth. It is finally given to the mouth of a sorcerer, who conveys it mixed with a hundred lies. If anything proves true, people will say, "Didn't he tell us on such-and-such day that such-and-such would occur, and we found it to be true?" Fortune tellers by "reading" or "spiritual consultation", give the client advice and predictions which are said to have come from spirits or in visions:

a) Alectromancy: by observation of a rooster pecking at grain 
b) Astrology: by the movements of celestial bodies

c) Astromancy: by the stars

d) Augury: by the flight of birds

e) Bazi or four pillars: by hour, day, month, and year of birth

f) Bibliomancy: by books; frequently, but not always, religious texts

g) Cartomancy: by playing cards, tarot cards, or oracle cards

h) Ceromancy: by patterns in melting or dripping wax

i) Chiromancy: by the shape of the hands and lines in the palms

j) Chronomancy: by determination of lucky and unlucky days

k) Clairvoyance: by spiritual vision or inner sight

l) Cleromancy: by casting of lots, or casting bones or stones

m) Cold reading: by using visual and aural clues

n) Crystallomancy: by crystal ball

o) Extispicy: by the entrails of animals

p) Face reading: by means of variations in face and head shape

q) Feng shui: by earthen harmony

r) Gastromancy: by stomach-based ventriloquism (historically)

s) Geomancy: by markings in the ground, sand, earth, or soil

t) Haruspicy: by the livers of sacrificed animals

u) Horary astrology: the astrology of the time the question was asked

v) Hydromancy: by water

w) I Ching divination: by yarrow stalks or coins and the I Ching

x) Kau cim by means of numbered bamboo sticks shaken from a tube

y) Lithomancy: by stones or gems

z) Necromancy: by the dead, or by spirits or souls of the dead

aa) Nephelomancy: by shapes of clouds

bb) Numerology: by numbers

cc) Oneiromancy: by dreams

dd) Onomancy: by names ee) Palmistry: by lines and mounds on the hand

ff) Parrot astrology: by parakeets picking up fortune cards

gg) Paper fortune teller: origami used in fortune-telling games

hh) Pendulum reading: by the movements of a suspended object

ii) Pyromancy: by gazing into fire

jj) Rhabdomancy: divination by rods

kk) Runecasting or Runic divination: by runes

II) Scrying: by looking at or into reflective objects

$\mathrm{mm}$ ) Spirit board: by planchette or talking board

nn) Taromancy: by a form of cartomancy using tarot cards

oo) Tasseography or tasseomancy: by tea leaves or coffee grounds

pp) Ureamancy: by gazing upon the foamy froth of urine created within water

The contract is signed between the Fortune teller and Shaytan to target the person or family or materialistic object etc. The servant Jinn operate with the Qareen, the Jinn attached to every human being since his birth. It is this Qareen which whispers to our base desires and constantly tries to divert us from righteousness. The Prophet (sallallahu Alaihi wa sallam) said: "Every one of you has been assigned a companion from the Jinn. (Muslim - Eng. Trans. Vol.4, p.1472, No.6757) Qareen communicates with The servant Jinn inform about everything in the past and somehow future if something was already finalized (booked tickets, signed contract). The servant Jinn inform the Fortune teller, so people without knowledge will be amazed and will trust the Fortune teller knowing the past and somehow the future. Abu Hurairah (may Allah be pleased with him) narrated that the Prophet (sallallahu Alaihi wa sallam) said: "Whosoever approaches a Fortune-teller and believes in what he says, has disbelieved in what was revealed to Muhammad".

\section{How Black Magic Spells Are Done}

There are many ways Black Magic spells are done, by making the victim eat or drink food or beverage that has been previously bound with black magic. Photographs of the victim are used to invoke a black magic curse. If a black magician obtains a photo of you or something you own or possess-for instance a piece of clothing or jewelry or the hair, the nail-these items could be used against you. Some black magicians can even create a liquid spell which may be spilled over a piece of land or an object to create a black magic curse. Taweez, Amulet, String, Thread, Talisman, papers with letters using Quranic verses, numbers are also used for Black Magic. Uqbah ibn 'Amir narrates that the Messenger of Allah said: "If anyone wears 
an amulet (taweez), may Allah not help him in fulfilling his wish. If anyone wears a sea-shell around his neck, may Allah give him no peace."(Narrated by Ahmad and Al-Hakim). The Messenger of Allah (sallallahu alaihi wa sallam) warned: "It is not permissible to tie this string or any other kind of amulets" (Hadith)

"Whoever hangs up an amulet, may Allah not fulfill his need". "Whoever hangs up anything will be abandoned to its care," "Whoever hangs up an amulet has committed shirk." Prophet (sallallahu alaihi wa sallam) saw a man on whose hand was a bracelet of brass: "What is this bracelet?" He said, "It is to prevent weakness." He said, "Take it off, for it will only make you weaker." (Narrated by Ibn Maajah) Some people without knowledge go to Fortune teller asking to pray for their children, parents, brothers and sisters with good intention but they do not know the catastrophic consequences for themselves and their families as the Evil activity of the Fortune tellers involve the army of Shayateen. These people think that they did well but, in the reality, they create problems after problems for entire family. Some asking to bless the marriage in the family but, the army of Shayateen will be sent to break marriage or to cause infertility.

Contract between Magician and Shaytan with the purpose

i. Marriage: to break

ii. Infertility- to cause

iii. Miscarriage-to cause

iv. To cause Sexual disorders

v. To prevent husband to have intimacy with his wife

vi. Family relationship- to break

vii. Health- diseases to cause

viii. Business- to break

ix. Job: to lose

x. House: to deteriorate,

xi. Fire: to cause

xii. Wealth: to destroy

xiii. Life: to ruin, to kill

xiv. Bad luck from all sides

\section{Black Magic Symptoms}

a. Hatred, Headache, strange, aggressive behavior when Quran recitation or Adhan

b. Sudden change of the behavior, sudden aggression with Negative Ions treatment ( )

c. Marriage: breaking d. Sudden change of the heart: argue, hatred, impossibility to have sexual life, wants to kill her

e. Impossibility to get married

f. Breakup in relations

g. Absence of happiness and peace

h. Suicide attempts

i. Financial loss, property loss

j. Black circles around the eyes

k. Nail becomes blue

l. No interest in the everything

m. Insomnia or oversleeping

n. Appetite lost, weight lost

o. Infertility

p. Miscarriage

q. Sexual problems

r. Menstrual irregularity

s. Premature Menopause

t. Seizure

u. Psychological problems

v. Health problems

w. Immediate change of the character or personality: quite person previously starts to argue, suddenly cursing husband, mother, family

x. Forgetfulness

y. Speaking suddenly fluently foreign language

z. Sudden increase of the strength, power (5 men against 1 woman)

aa. Isolation, seclusion

bb. Bad hygiene (Jinn hate shower, water)

cc. Teeth and gum painful and bleeding

dd. Bad body smell, mouth smell

ee. Like to stay in the toilet

ff. Large, profound wound

gg. During the night, Jinn go to the graveyard, go under the tree

hh. False Court case 


\section{When Quran is Recited over the Victim}

a. The most typical reaction of sorcery is heat in the whole body: the sorcery is burning.

b. The person may also feel things exiting from him: the sorcery is leaving.

c. When person feels heavy or goose bumps, does not bare Quran being recited, cannot breathe or gets anxious - that shows presence of Jinn.

d. The person may relax, calm down and fall asleep: this may mean two things: either sorcery has been set in a person to make them anxious: the Quran reduces the effect of sorcery and the person relaxes; or sorcery was aimed to make the victim feel tired all the time. Even after a good night sleep they will feel tired: Quran provides relieving sleep for them and once they wake up they feel rested.

e. When a person shows few different reactions, it means that they have combined problems. That is usually followed by tiredness and exhaustion.

f. No or little reaction: the person has a little or no problem at all, or the Jinn are outside the body and affecting them from the outside. In this case, a simple reading allows to burn the connection of the Jinn with the person without reaching the jinn and that is enough to disconnect him. The reciter might find the task difficult.

g. If a person does not react to the Quran recitation, but they have other clear symptoms of sorcery or Jinn possession, then the treatment is still required. Obvious signs would be easily seen from the quality of life of the victim, they body, health, well-being, behavior, mental state and dreams. Quran recitation is not an exclusive diagnosis tool for sorcery or Jinn possession.

h. Experiencing a headache is due to Jinn in the body or outside of the body. It also may be that sorcery affected one's head or a sorcery symbol hanged which aims at the head of a victim.

Allah had forbidden the means that usually lead to spreading evil among the people and causing harm. "And indeed, they knew that the buyers of it (magic) would have no share in the Hereafter. And how bad indeed was that for which they sold their own selves, if they but knew." (Quran, Al Baqarah 2:102) The Prophet (sallallahu Alaihi wa sallam) said: "The prescribed punishment for the magician is that he be executed by the sword" (Authentic, Tirmidhi).

\section{JINN POSSESSION}

Allah (Subhanahu wa ta'ala) has given to Jinn the ability to dwell inside human beings but this can only happen by His permission, Glory be to Him. Many sorcerers and magicians will communicate with the Jinn and tell them to possess an individual. But before doing that, the Jinn makes a contract with the magician that he/she must do an act of disbelief like stamp on the Quran or write Quran verses with the menstrual blood or defecate on the Quran or have unlawful sexual intercourse. The magician will then command the Evil Jinn to enter the body of a person and the Jinn will do so except those whom Allah (Subhanahu wa ta'ala) wishes to protect.

Jinn can be attracted by the person and possess him/her.

\section{Jinn Attraction}

a) Beautiful female and male

b) Attractive dress, colors, hair, make up

c) Attractive seductive behavior

d) Sexual desire

e) Strong Perfume

f) Naked, undressed, uncovered (mostly female)

g) Menstrual blood (required Ghusl after menstruation)

h) Reproductive fluids (semen, vaginal humidity) (required Ghusl after intercourse)

i) Impurity

j) Acts of Disbelief

\section{Jinn Do Not Like}

i. Quran

ii. Azhan- call for the prayer

iii. Remembrance of Allah

iv. $\quad$ Negative Ions (Quran Al Anfal 8:11)

v. Purification: Whudu, Ghusl

vi. Cleanness

vii. Good smell

\section{Jinn Possession reasons:}

\section{Table 10:}

\begin{tabular}{|c|c|c|}
\hline \multicolumn{3}{|r|}{ JINN POSSESSION REASONS } \\
\hline 1 & DESIRE & $\begin{array}{l}\text { DESIRE OF POWER } \\
\text { DESIRE OF CONTROL (CONTROL OF LIFE) } \\
\text { ATTRACTIONLOVE }\end{array}$ \\
\hline 2 & REVENGE & $\begin{array}{l}\text { WHEN THE PERSON COULD UNINTENTIONALLY HARM JINN } \\
\text { (THROWWNG HOT WATER, STONE, URINATING, JUMPING OR EVEN } \\
\text { KILLING) }\end{array}$ \\
\hline 3 & $\begin{array}{l}\text { JNN ISEVIL AND SIMPLY } \\
\text { WANT TOHARM }\end{array}$ & MISCHIEF, CREATE CONFUSION,DISCOMIORT,HARM \\
\hline 4 & MISGUIDANCE & IDOLATRY, ACTS OF DISBELIEF \\
\hline 5 & RIBA & $\begin{array}{l}\text { "Those who consume interest cannot stand [on the Day of } \\
\text { Resurrection] except as one stands who is being beaten by } \\
\text { Satan into insanity." (Quran, Al Baqarah 2:275) }\end{array}$ \\
\hline 6 & $\begin{array}{l}\text { TURNING AWAY FROM THE } \\
\text { REMEMBRANCE OF ALLAH }\end{array}$ & $\begin{array}{l}\text { "And whoever is blinded from remembrance of the Most } \\
\text { Merciful - We appoint for him a devil, and he is to him a } \\
\text { companion." (Quran, Al Zukhruf 43:36) }\end{array}$ \\
\hline 7 & BLACK MAGIC & JNN SENT BY BLACK MAGIC \\
\hline
\end{tabular}




\section{Jinn Possession Signs and Symptoms}

a) Reaction to Quran (turning away and reacting strongly when hearing Quran or Adhan (call for the prayer); fainting, seizures, falling when Quran is read over the Jinn possessed person; the Jinn may speak when Quran is recited

b) Reaction to the Negative Ions Treatment (sudden change of the behavior, aggression, refusal or removal of the Negative Ions treatment (products)

c) Female and Male infertility

d) Repeated miscarriage

e) Sexual disorders

f) Menstrual irregularity

g) Hormonal misbalance

h) Premature Menopause

i) Endometriosis

j) Pelvic pain

k) Dysmenorrhea, Dyspareunia

l) Ovarian Cysts, Fibroids, Thin Endometrium

m) Procrastination in doing good acts or praying

n) Constant laziness

o) Recurring aggression

p) Loss of senses while awake

q) Constant headaches moving from one part to another of the head

r) Recurring nightmares

s) Laughing while asleep

t) Sleepwalking

u) Insomnia or oversleeping

v) Withdrawal from society and love of loneliness

w) Face becomes yellow and pale

x) Sweating and urinating a great deal.

y) Tachycardia with normal heart investigations

z) Health problems with no medical cause which doctors cannot identify

aa) Depression and Anxiety

bb) Pain in lower back and shoulders cc) Inexplicable bruising or marks appearing spontaneously

dd) Black circles under the eyes

ee) Critical illness/possibly of more than one family member/ doctors cannot find the cause

Medicines do not work

ff) Heart attacks/intense heart pain

gg) Cancer

hh) Psychiatric diseases: Depression, Anxiety, Bipolar, Schizophrenia, Obsessive Compulsive Disorder (OCD), Dissociative Disorders

ii) Neurological diseases: Epilepsy, Multiples Sclerosis, Alzheimer, Huntington, Autism...

jj) Suicidal attempts/Family members contemplating suicide, impulses to self-torture

kk) Self-destruction through substance abuse/addictions.

II) The person moves or speaks constantly without his will

$\mathrm{mm}$ ) Ravishing hunger, hungry again not long after eating

$\mathrm{nn}$ Incredible thirst possibly caused also by stress

oo) Your waking state is like a horror movie every minute with no sense of relief except short periods while sleeping. Waking is torture

pp) Teeth, gum with pain and bleeding

\section{EVIL EYE}

Evil Eye is like an arrow which comes from the soul of the one who envies towards the one who is envied and on whom the Evil Eye is put; sometimes it hits him and sometimes it misses. If the target is exposed and unprotected it will affect him but if the target is cautious and armed the arrow will have no effect and may even come back on the one who launched it. (extracted from Zaad Al Ma'ad) According to Shaykh Khalid Al-Hibshi (may Allah be pleased with him), it is something evil that comes out of the soul and then attacks the person. The Evil Eye is an illness which some people (not everyone) carry. It entails looking at a blessing which someone has within them or from that which they possess from worldly possessions with amazement or liking it. This then leads to dwelling on the matter, continually looking at the person who has the thing which he feels jealous towards and subsequently leading to an attack described as rays emitting from a person's eyes (and their soul) and subsequently affecting him physically/ mentally causing him to become ill and even die. One doesn't need to physically look at someone to give them Evil Eye, even a blind person can give the Evil Eye. One can even give the Evil Eye merely by listening to the description of a person's blessings. (Zaad Al Ma'ad: volume 4 
page 149) Everyone who gives the Evil Eye is jealous but not every jealous person gives the Evil Eye.

The evidence for this is that Ayn can even be given to yourself, your own children and even when joking. The evidence for this comes from the following Hadith: "Whoever among you sees something in himself or in his possessions or in his brother that he likes, let him pray for blessings for it because the Evil Eye is real." (Ibn al-Sunni in A'mal al-Yawm wal-Laylah, page 168; Al-Haakim, 4/216. Classed as Sahih by al-Albaani in Al-Kalim at-Tayyib, page 243) This Hadith explains that a person may harm himself, his wealth, his children, his wife etc by the Evil Eye. The Prophet (sallallahu Alaihi wa sallam) said: "The Evil Eye is real and if anything were to overtake Qadr (divine decree), it would have been the Evil Eye". The Messenger of Allah (sallallahu Alaihi wa sallam) said: "The Evil Eye is real and can bring down a person from a high mountain." (Sahih al Jami' 4146). "The Evil Eye can take a person into grave (can cause death) and takes the camel into the cooking pot." (Narrated by Jabir Bin Abdullah). The Evil Eye can be given by a human or by Jinn. It is also known that animals can give the Evil Eye too when they look at something. And Allah knows best. Allah (subhanahu wa ta'ala) also says: "Or do they envy people (i.e. Prophet Muhammad and his followers) for what Allah has given them of His bounty? But we had already given the family of Ibraheem the Scripture and wisdom and conferred upon them a great kingdom (Quran, An-Nisa 4:54) Allah (subhanahu wa ta'ala) commanded to seek refuge with Him from the envier: "And from the evil of the envier when he envies." (Quran, Al-Falaq 113) "And indeed, those who disbelieve would almost make you slip with their eyes when they hear the message, and they say, "Indeed, he is mad." (Quran, Al-Qalam 68: 51)

Hadith narrated from Abdullah ibn Abbas (may Allah be pleased with him) says, "A'odhu bi kalimaat-Illaah it-taamah min kulli shaytaanin wa haammah wa min kulli a'ynin laammah (I seek refuge in the perfect words of Allah, from every devil and vermin and from every envious eye)." (Bukhari - 3191). The meaning of "vermin" (haammah) is lethally poisonous animals and insects. The word "Haasid" (envier) is more general in meaning than the word Ayn (one who puts the Evil Eye on another).

\section{Different degree of Envy}

a. A person wants the blessing to be taken away from his Muslim brother/ sister even if it does not come to him; rather he does not like Allah to bless anyone else as that upsets him. This person may actively work to remove the bounty from another person without necessarily destroying the bounty itself. He may do this with his speech or actions and may do whatever it takes to bring an end to the blessing from the envied person.

b. Where a person wants a blessing to be taken away from someone else because he hopes that it will come to him. This person does not just seek to remove that bounty from another person but also works to get the bounty for himself.
Hasad (destructive jealousy) causes a great deal of harm. Narrated from Az-Zubayr ibn al-A'waam (may Allah be pleased with him), the Prophet (sallallahu alaihi wa sallam) said: "There has come to you a disease of the nations before you, jealousy and hatred. This is the 'shaver' (destroyer); I do not say that it shaves hair but that it shaves (destroys) faith. By the One in Whose Hand is my soul, you will not enter Paradise until you believe, and you will not believe until you love one another. Shall I not tell you of that which will strengthen love between you? Spread the greetings of peace amongst yourselves." (Tirmidhi, 2434). Shaykh Ibn Taymiyyah (may Allah be pleased with him) said in his book Amraad al-Quloob (diseases of the heart): "Whoever finds in himself any hasad towards another has to try to neutralize it by means of attaining taqwa (piety, consciousness of Allah) and Sabr (patience). He should hate that the feeling of hasad is in himself... But the one who does wrong to his brother by word or deed will be punished for that. However, the one who fears Allah (subhanahu wa ta'ala) and is patient is not included amongst the wrongdoers and Allah (subhanahu wa ta'ala) will benefit him by his taqwa." Nobody is free from hasad, but the noble person hides it whilst the base person shows it." A person will not be brought to account for whatever crosses his mind, but he will be brought to account for what he says and does. The Prophet (sallallahu alaihi wa sallam) said: "Allah will forgive my nation for their mistakes, what they forget and what they are forced to do (through coercion)." (Bukhari - 2033)

Narrated from Sahl ibn Haneef (may Allah be pleased with him) that the Prophet (sallallahu alaihi wa sallam) came out and traveled with him towards Makkah until they were in the mountain pass of Al-Kharar in Al-Jahfah. There Sahl ibn Haneef did ghusl (bathed), and he was a handsome white-skinned man with beautiful skin. Amir ibn Rabee'ah, one of Banu Adiyy ibn K'ab looked at him whilst he was doing ghusl and said, "I have never seen such skin as beautiful as this, not even the skin of a virgin," upon those words Sahl fell to the ground. They went to the Messenger of Allah and said, "O Messenger of Allah, can you do anything for Sahl because by Allah he cannot raise his head." He said, "Do you accuse anyone with regard to him?" They said, "Amir ibn Rabee'ah looked at him." So, the Messenger of Allah called Amir and rebuked him strongly. He said, "Why would one of you kill his brother? If you see something that you like, then pray for blessings for him." Then he said to him, "Wash yourself for him." So, he washed his face, hands, forearms, knees and the sides of his feet, and inside his izaar (lower garment) in the vessel. Then that water was poured over him (i.e. Sahl) and a man poured it over his head and back from behind. He did that to him then Sahl got up and joined the people and there was nothing wrong with him. (Ahmad, Malik, An-Nasai' and Ibn Hibban; classed as Sahih (authentic) by al-Albani in Al-Mishkat).

Narrated from Abdullah ibn Abbas (may Allah be pleased with him), the Messenger of Allah (sallallahu alaihi wa sallam) said: "The influence of the Evil Eye is a fact. If anything were to precede the divine decree it would have been the influence of an Evil Eye. 
Therefore, when you are asked to take a bath (as a cure) from the influence of the Evil Eye, you should take a bath.' (Sahih Muslim Hadith 5427) Therefore the person who has been afflicted by Ayn should try to get the water of the person who has afflicted him and bath with it. Narrated Umm Salaamah (may Allah be pleased with him), the Prophet (sallallahu alaihi wa sallam) once saw a young girl who had a certain expression on her face, so he said: "Seek an Islamic prayer formula for her because she is touched by the Evil Eye." (Bukhari, Muslim, Abu Naim, Tabari) Prophet (sallallahu alaihi wa sallam) saw a girl in her house whose face had a black spot, so he said: "She is under the effect of an Evil Eye, so treat her with Ruqya" (Al-Tib Al- Nawabi, 164)

\section{The Effects of The Evil Eye}

Sheikh Khalid Al-Hibshi (may Allah be pleased with him) says that Ayn has a tremendous destructive power. It has an influence in all areas of a person's life, whether religious affairs, worldly affairs, moral characteristics etc. Some of the effects are summarized below:

a. Effect on the minds: IQ wit, memory, ability to focus, understanding and assimilation.

b. Effect of the health: diseases, infertility, aging

c. Effect on the livelihood: wealth, income, provisions etc.

d. Effect on beauty: hair, face, skin color, the body etc.

e. Effect on religion: worship, humility, character, integrity etc.

f. Effect on a person's morality: modesty, truthfulness, courage, good characteristics etc.

g. Effect on marital and family life: happiness, infertility, pregnancy, childbirth, miscarriage, raising and loving children, discord etc.

h. Effect on ages: age relative to appearance, death, etc.

i. Effect on the body: power, speed and activity, wellness, skills etc.

j. Effect on livestock: camels, bringing down birds from the sky etc.

k. Effects on nature: plants, trees and fruits, damage, burns, ripeness, shrivel and die etc.

l. Effect on inanimate objects: cars, property, all kinds of devices, gold, women's cosmetic application or products.

Narrated by Abu Hurairah (may Allah be pleased with him) said: The Messenger of Allah (sallallahu alaihi wa sallam) said: "My nation will be stricken with the disease of the other nations." They said: "What is the disease of the other nations?" He said: "Insolence, arrogance, accumulation of wealth, competition in worldly gains, mutual hatred and envy until there will be wrongdoing and then killing." (Al Tabaraani in Al-Awsat; Ibn Abi'l-Dunya)

\section{Evil Eye Signs and Symptoms}
a) Constant yawning
b) Constant burping
c) Constant Sneezing
d) Symptoms increase when reading or listening to the Qur'an

e) Itching when the person afflicted carries out an act for which the evil eye has been given, For example if the evil eye has been given because of a person's wealth, they will start itching when they come into contact with money

f) Appearance of spots and boils on the body/ face

g) Hot and could flushes for no reason

h) Heat or cold in the limbs

i) Headaches that move from one part of the head to another;

j) Face becomes yellow pale

k) Sweating and urinating a great deal

l) Weak appetite

m) Tingling

n) Palpitations

o) Pain in the lower back and shoulders

p) Depression and Anxiety

q) Insomnia or oversleeping

r) Strong reactions due to abnormal fears

s) Withdrawal and love of solitude

t) Apathy, Tiredness and Laziness

u) Health problems with doctors can nor explain and going from one problem to another

v) Chest Tightness

w) Insomnia or oversleeping

x) Waswasah (constant whispering)

y) Weight gain without eating more

z) Cancer

aa) Psychological conditions such as delusion and fear

bb) Forgetfulness and sleepiness while studying, reading Quran or going to school etc 
cc) Allergies, rhinitis and sinusitis

dd) Cold/ flu

ee) Hair Loss

ff) Darkening under the eyes

gg) Spots under the skin

hh) Stomach Pain which doctors cannot explain

ii) The desire to get out of the house or hatred in staying indoors

jj) The feeling of death and despair

kk) Seeing dead people in your sleep, lizards or cats

11) To see people who have given you the evil eye looking at you in a strange and scary way

$\mathrm{mm}$ ) Seeing ants in the house

nn) Children crying constantly for no reason

oo) Children stopping growing

Some of the symptoms of Black Magic, Jinn Possession and Evil Eye are specific and some may have other origins. Satan takes advantage of the man's disobedience and seduces him. Allah says: "And recite to them, [0 Muhammad], the news of him to whom we gave [knowledge of] Our signs, but he detached himself from them; so Satan pursued him, and he became of the deviators." (Quran Al-A'raf 7:175). Allah says: "See you not that We have sent the Shayateen (devils) against the disbelievers to push them to do evil." (Quran, Maryam 19:83)

The Evil Jinn directly or indirectly will do everything to create Infertility or miscarriage or ectopic pregnancy or sexual disorders or prevent intercourse to happen to prevent pregnancy. Shaytan can create any disease including endometriosis, ovarian cysts, poor ovarian reserve, premature menopause, menstrual irregularity, hormonal misbalance, fibroids, thin endometrium, pelvic pain, absence of libido, frigidity, vaginism, vaginal pain, burning, irritation; squeeze the tubes. And in man any disorder to prevent the intercourse and pregnancy: poor semen quality or azoospermia, retrograde ejaculation, impotence, no sexual desire. Jinn can induce the bleeding every time the husband approaches or continuous bleeding. In Islam the intercourses during menstruation are forbidden as the Jinn is attracted to the menstrual blood. Total purification, Ghusl, is obligatory after finishing menstruation. "And they ask you about menstruation. Say, "It is haram, so keep away from wives during menstruation. And do not approach them until they are pure. And when they have purified themselves, then come to them from where Allah has ordained for you. Indeed, Allah loves those who are constantly repentant and loves those who purify themselves." (Quran, Al Baqarah 2:222) Beautiful wife can appear to his husband ugly, unpleasant by the illusion created by Jinn or wife or husband starts to hate, harm each other and dispute as Jinn wants them to separate. And if the couple did In-Vitro Fertilization treatment, fertilization may not occur, or the embryos will be with chromosomal abnormalities, or no pregnancy or miscarriage will happen. The cases of the Infertility created by Jinn were described in my articles $[13,14]$.

\section{Ruqya and Negative Ions Treatment}

Sheikh Ibn Taymiyyah (may Allah be pleased with him) mentions that it is obligatory to aid one's brother who is being wronged. The cure of any illness, infertility is only from Allah. "And with Him are the keys of the unseen; none knows them except Him. And He knows what is on the land and in the sea. Not a leaf falls but that He knows it. And no grain is there within the darkness's of the earth and no moist or dry (thing) but that it is (written) in a clear record." Quran, Al An'am 6:59) Ruqya and Negative Treatment have Curative and preventive effects and should be done every day. Ruqya doesn't require any skills; it is the recitation of the certain verses of the Noble Quran. Surah Al-Fatiha has great importance as it is known as "Mother of Quran". The 'Muawwidaat', seek refuge with Allah against any Evil by reciting Surah Al-Falaq 113 and Surah An-Naas114. Surah Ayatul Kursi after each prayer, before going to sleep, in Ruqya. Jinn and Shaytan do not come close to the house in which Ayatul Kursi is recited. (Tirmidhi Al Targheeb Wal Tarheeb Lilmanzari vol.2 pp.631) "By reciting it (Ayatul Kursi), there will be a guardian appointed over you from Allah who will protect you during the night, and Satan will not be able to come near you until morning." (Bukhari, book 9, Hadith 30)

The Shaytan revealed to Abu Hurayrah (may Allah be pleased with him): Surah Al Baqarah to recite/listen every day. The Prophet (sallallahu alaihi wa sallam) said: "Do not make your houses like graves, for Satan runs away from a house in which Al Baqarah chapter is recited." (Muslim) The Messenger of Allah (sallallahu alaihi wa sallam) said: "Whoever recites the last two verses of Surah Al Baqarah at night, that will suffice him." (Bukhari, 4723; Muslim, 807) For simple guide of Self Ruqya, please refer to [68]. The best is to recite by the affected person (if possible) or by his family members before seeking for medical treatment. In my personal experience, Allah cured by Ruqya non-Muslim people as it is only Allah knows your heart and the future and Allah is the Most Merciful to all His creatures.

\section{Negative Ions}

Allah created the Nature which has amazing healing power by high concentration of the Negative Ions (thunderstorm, rain, waterfall, sea, mountain, forest). The Negative Ions are the best treatment against Positive Ions, the main cause of almost all diseases, infertility and aging. [9-11]. "(Remember) when He overwhelmed you with drowsiness (giving) security from Him and sent down upon you from the sky, rain by which to purify you and remove from you the evil (suggestions) of Satan and to make steadfast your hearts and plant firmly thereby your feet." (Quran, Al Anfal 8:11) 
Jinn are considered Plasma beast creatures, from Plasma Interior of the Sun and contain Negative and Positive Ions [12]. As Evil Jinn is removed by the Rain (Negative Ions), the Jinn are Positive ions. Allah Almighty gives us another way of the protection from the Evil Jinn [13]. The best Negative Ions are Ion box containing 20 million Negative Ions, Anion Sanitary Napkins and many others.

\section{PROTECTIVE ACTIONS \& PRECAUTIONARY MEASURES AGAINST SHAYTAN}

\section{Perform five obligatory prayers daily (the best Medicine)}

\section{Dua in different occasions (www.duas.com):}

i. Dua for entering and leaving the toilet

ii. Dua for entering and leaving the house

iii. Dua for setting foot in a new place:

iv. Dua for entering and leaving Masjid

v. Dua for new clothes, for dressing and undressing

vi. Dua before eating and after eating

vii. Dua before sexual intercourse

Dua (supplication) is the enemy of calamity; it wards it off and remedies it, prevents it befalling, and relieves it if it has happened. Al-Haakim narrated in his Sahih that A'ishah said that the Messenger of Allah (sallallahu alaihi wa sallam) said: "Caution is to no avail against the Divine decree and Dua is useful with regard to what has befallen and what has not yet befallen. Calamity may descend and be met by Dua, and they wrestle until the Day of Resurrection". Saying Bismillaah (in the Name of Allah) before entering home, before eating or drinking, and before having intercourse will keep the Shaytan from entering the house or partaking with a person in his food, drink and sexual activity. Similarly, mentioning the name of Allah before entering the toilet or taking off one's clothes will prevent the Jinn from seeing a person's 'awrah or harming him, as the Prophet (sallallahu alaihi wa sallam) said, "To put a barrier that will prevent the Jinn from seeing the 'awrah of the sons of Adam, let any one of you say 'Bismillah' when entering the toilet." (Reported by al-Tirmidhi, 551; Saheeh al-Jaami', 3611).

The Hadith telling, the Shayateen will stand by the door, when the person comes they listen, if he says Bismillah, Assalaamu 'Alaikum - if he remembers Allah the head Shaytan will say "go back, go back you have no place and no food here." But when you come into the house silent or saying any words other than the remembrance of Allah, He says, 'Ok come here you have a place to sleep you have food come, come" and they come into your house. Because the Jinn can see us while we cannot see them, the Prophet Muhammad (sallallahu alaihi wa sallam) taught us many ways to protect ourselves from their harm, such as seeking refuge in Allah from the accursed Satan: "And say, "My Lord, I seek refuge in You from the incitements of the devils. And I seek refuge in You, my Lord, lest they be present with me." (Quran Al Mu'minun 23:97-98)

\section{Initiating Marital Life with Salah}

Abdullah Ibn Mas'ood (may Allah be pleased with him) said: "On your wedding night; that is on the night when the marriage is to be consummated for the first time; and before intercourse, do two rak'as and ask your wife to follow suit behind you, and say the following invocation: Allaahumma barik li fi ahlee, wa barik lahum fiyya, Allaahumma ijma' baynanaa ma jama'ta bikhayr, wa farriq baynanaa idhaa farraqta bikhayr. O Allah! Make my wife blessed for me and make me blessed for her. O Allah! If You unite us, unite us on what is good, and if you separate us, separate us on what is good. (Transmitted by At-Tabarani and classed by Al-Albani as authentic.)

\section{Protection from the Satan before and after the intercourse}

It is narrated from Imam as-Sadiq (may Allah be pleased with him): "Whenever a person makes love to his wife, Satan is present. Then, if the name of Allah is remembered, Satan goes far from there, but if the act occurs and the name of Allah is not remembered, Satan takes part in that he is one with the sperm". Say Bismillah before the intercourse and following Dua to be protected from Shaytan. Ibn 'Abbaas (may Allah be pleased with him) reported: "The Prophet said: "If you say the following invocation during sexual intercourse, and a baby is conceived, Satan would never harm that baby." "O Allah! Keep us away from Satan and keep Satan away from any blessing you bestow on us." (Bukhari (Fath Al-Bari: 1/291) and Muslim.) Jinn can take part in the sexual intercourse with his wife if they did not say Bismillah and the above invocation. Pregnancy issued from Jinn-Human sexual life may give disabled children. After the intercourse the total body purification, Ghusl, is obligatory as Jinn is attracted by the semen and vaginal humidity.

\section{Make Wudhu (purification) before going to bed, recite Aayatul Kursi}

More Wudhu, more prayers will give more protection and more rewards from Allah

\section{Ignore Satanic whispers (waswasah)}

The unwanted obsessive thoughts are called waswasah, whispered into the minds and hearts of people by Shaytan. "Say: 'I seek refuge with Allah, the Lord of mankind, the King of mankind, the God of mankind, from the evil of the whispers of the Devil, who whispers in the hearts of men" (Quran, a Nas 114). And the Prophet Muhammad (sallallahu alaihi wa sallam) said: "Shaytan comes to one of you and says, 'Who created so-and-so and so-and-so?' till he says, 'Who has created your Lord?' So, when he inspires such a question, one should seek refuge with Allah and give up such thoughts" (Bukhari and Muslim).

\section{Constant remembrance of Allah through Dhikr}

We should use Allah's remembrance (Dhikr) to ward off waswasah. Al-Nawawi (may Allah have mercy on him) said that "when the Shaytan hears Dhikr (remembrance of Allah) he slinks away, and Laa ilaaha ill-Allah is the best of Dhikr, and the most 
effective remedy for warding off waswasah is to remember Allah a great deal." So, do a lot of remembrance (adhkar), the remembrance of the morning and evening, for entering the house, exiting the house, entering the toilet, exiting the toilet, entering the mosque, exiting the mosque, before driving your car etc. "Verily, in the remembrance of Allah do hearts find rest." (Quran, Ar-Ra'd 13:28) "And whoever is blinded from remembrance of the Most Merciful - We appoint for him a devil, and he is to him a companion. And indeed, the devils avert them from the way (of guidance) while they think that they are [rightly] guided." (Quran, Az-Zukhruf 43:3638) "And whoever turns away from My remembrance - indeed, he will have a depressed life, and We will gather him on the Day of Resurrection blind." (Quran, Taha 20:124)

\section{Faith and Trust in Allah}

"And whoever fears Allah and keeps his duty to Him, He will make a way for him to get out (of every difficulty). And he will provide him from (sources) he never could imagine" (Quran, AtTalaq: 2-3). "So, when you intend to recite the Quran, seek refuge with Allah from Shaytan, the outcast. Verily! He has no power over those who believe and put their trust only in their Lord (Allah). His power is over those who obey and follow him (Shaytan) and those who join partners with Allah" (Quran A Nahl 16:99-100). "Indeed, over My (believing) servants there is for you no authority. And sufficient is your Lord as Disposer of affairs." (Quran, Al Isra 17:65) "And Iblees had already confirmed through them his assumption, so they followed him, except for a party of believers. And he had over them no authority except (it was decreed) that We might make evident who believes in the Hereafter from who is thereof in doubt. And your Lord, over all things, is Guardian." (Quran, Saba 34:20,21) "Say (O Muhammad): "Verily, my Salah (prayer), my sacrifice, my living, and my dying are for Allah, the Lord of the Alamin (mankind, jinn and all that exists)." (Quran, Al-An'aam 6:162)" Truly, Allah defends those who believe." (Quran, Al-Hajj 22:38)

\section{Fearing Allah and not His Creation}

"Satan threatens you with poverty and orders you to immorality, while Allah promises you forgiveness from Him and bounty. And Allah is all-Encompassing and Knowing." (Quran, Al Baqarah 2:268) "That is only Satan who frightens (you) of his supporters. So, fear them not, but fear Me, if you are (indeed) believers." (Quran, AlImran 3:175) The Prophet (sallallahu alaihi wa sallam) said to 'Umar ibn al-Khattaab: "So the Shayateen - the Jinn, they are scared of the Believers, but they have a sense, they can feel the fear and fright of mankind. So, if you become scared of Jinn, they become brave and they start scaring you." The Jinn are a creation that fears the Believers most. "Say, "Indeed, my prayer, my rites of sacrifice, my living and my dying are for Allah, Lord of the worlds." (Quran, Al-An'am 6:162)

\section{Obtaining Islamic knowledge (from the Right Sources)}

Taking heed of Satan's ways and becoming aware of his plans and goal can help us to be alert to his influence or persuasion and keep our defenses up. Imam Shafai said: "All humans are dead except those who have knowledge; and all those who have knowledge are asleep except those who do good deeds; and those who do good deeds are deceived except those who are sincere; and those who are sincere are always in a state of worry."

\section{Taking refuge and shelter in Allah}

"And if an Evil whisper comes to you from Shaytan (Satan), then seek refuge with Allah. Verily, He is All-Hearer, All-Knower" (Quran, Al-Aaraf: 200) This is what the Prophet (sallallahu alaihi wa sallam) did with the devil who put a flame of fire in his face, he said" I seek refuge in Allah from you, and I curse you with the curse of Allah." He said that three times.

\section{When Night comes as the Shayateen are Active during the Night}

It was narrated from Jaabir ibn 'Abd-Allaah (may Allah be pleased with him) that the Prophet (sallallahu alaihi wa sallam) said: "When the wings of the night spread or when evening comes - keep your children in, for the devils come out at that time. Then when part of the night has passed, let them go. And close the doors and mention the name of Allah (Bismillah), for the Shaytan does not open a closed door. And tie up your waterskins and mention Bismillah, and cover your vessels and mention Bismillah, even if you only put something over them, and extinguish your lamps." Narrated by al-Bukhaari (3280) and Muslim (2012): "Cover vessels, tie up waterskins, close doors and extinguish lamps, for the Shaytan does not loosen waterskins or open doors or uncover vessels."

\section{Islamic etiquettes and manners (code dress, lower the gaze) as a protection against Evil}

The Hijaab is a key element for protection against the Evil Eye. And since women are most likely to be afflicted by it, then it is one of the reasons why Allah (subhanahu wa ta'ala) made the Hijaab obligatory and that's why it is forbidden for believing women to display any of their beauty in front of non-mahrams (any person that a woman can marry). "And tell the believing women to reduce (some) of their vision and guard their private parts and not expose their adornment except that which (necessarily) appears thereof and to wrap (a portion of) their headcovers over their chests and not expose their adornment except to their husbands, their fathers, their husbands' fathers, their sons, their husbands' sons, their brothers, their brothers' sons, their sisters' sons, their women, that which their right hands possess, or those male attendants having no physical desire, or children who are not yet aware of the private aspects of women. And let them not stamp their feet to make known what they conceal of their adornment. And turn to Allah in repentance, all of you, $\mathrm{O}$ believers, that you might succeed." (Quran, A Noor 24:31) Do not stay in the state of impurity for a prolonged period.

\section{Do not stay in the state of impurity for a prolonged period}

Purification, Wudhu and Ghusl, and clean clothes, clean house protect from the Evil 


\section{Conclusion}

Knowing the Unseen World is important to be protected in this life and to avoid eternal life in the Hellfire. Protection and cure are only from Allah. Ruqya and Negative Ions are the best treatment for any illness and Infertility which should be done in first intention and on daily basis. "And God said, 'Oh humankind! Be dutiful to your Lord, who created you from a single person (Adam) and from Him (Adam) He created his wife (Eve), and from them both He created many men and women." (Quran, A Nisa 4:1) "And put your trust in Allah Alone; and enough is Allah as a Disposer of affairs." (Quran, Ahzaab 33:3)

\section{References}

1. Abu Ameenah Bilal Ibn Taymiyah's Essay on the Jinn (Demons).

2. Umar S Al-Ashqar (2003) The World of the Jinn and Devils in the Light of the Qur'an and Sunnah. International Islamic Publishing House.

3. Abul Mundhir Khaleel (2009) The Jinn and Human Sickness] Remedies in The Light Of The Quran and Sunnah.

4. Wahid Ibn Abdessalam Bali (2004) Sword against Black Magic \& Evil Magicians.
5. Abdul Azeez Bin Abdullah Bin Baaz The Ruling of Sorcery, FortuneTelling and Related Issues.

6. Khaled Al-Jeraisy "Self-Ruqya Treatment. Do it Yourself. Treat Your Family".

7. Muhammad Tim Humble Ruqya for patients.

8. Muhammad Tim Humble Simple Guide to Self- Ruqya.

9. Mira Bajirova (2017) Natural Pregnancy by Negative Ions in Young Woman with Premature Menopause, EC Gynecology.

10. Mira Bajirova (2017) Natural Pregnancy by Negative Ions in Young Woman with Poor Ovarian Reserve after Four Failed IVF, EC Gynecology.

11. Mira Bajirova (2017) Miraculous Effects of Negative Ions on Male Infertility, EC Gynecology.

12. Ibrahim B Syed The Jinn- A Scientific Analysis.

13. Mira Bajirova (2018) Infertility caused by Decreased Oxygen Utilization and Jinn 1(1): 47-58.

14. Mira Bajirova (2018) Ovarian Dermoid Cyst: Ruqya and Negative Ions Treatment, Journal of Clinical Review \& Case Reports.
Submission Link: Submit Article

DOI: 10.32474/OAJRSD.2018.01.000120

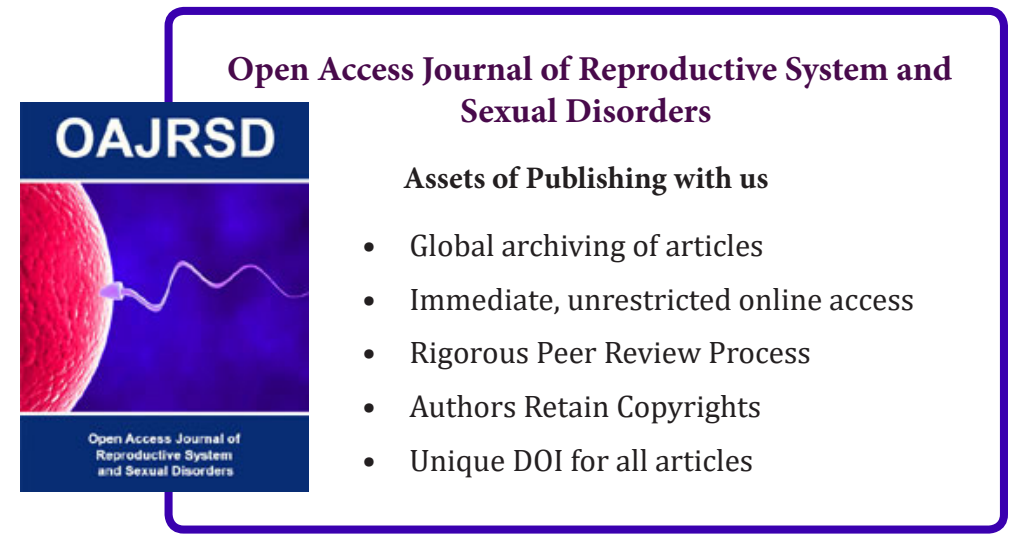

